\section{CITAÇÃO}

Pires, D., Mafra, P. (2016)

Micróbios: vilões ou heróis?,

Rev. Ciência Elem., V4 (04):027.

doi.org/10.24927/rce2016.027

\section{EDITOR}

José Ferreira Gomes,

Universidade do Porto

\section{COPYRIGHT}

(C) Casa das Ciências 2016.

Este artigo é de acesso livre, distribuído sob licença Creative Commons com a designação CC-BY-NC-SA 4.0, que permite a utilização e a partilha para fins não comerciais, desde que citado 0 autor e a fonte original do artigo.

\section{rce.casadasciencias.org}

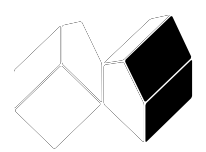

\title{
Micróbios: vilões ou heróis?
}

\author{
Delmina Pires ${ }^{*}$, Paulo Mafra \\ ESE - Instituto Politécnico de Bragança \\ *piresd@ipb.pt
}

Um dos desafios que hoje se coloca à escola é a necessidade de promover, a par da aquisição de conhecimento, o desenvolvimento de competências como o raciocínio, a argumentação crítica e a indagação científica, bem como a capacidade de cooperar, com responsabilidade e autonomia, na procura de soluções para problemas reais, aplicando o conhecimento adquirido. Em suma, é imprescindível desenvolver a literacia científica contribuindo para a formação de cidadãos esclarecidos e socialmente intervenientes.

Os conteúdos de ciências, estando muito presentes no quotidiano dos jovens, tornam-se fundamentais para o desenvolvimento das competências e capacidades atrás referidas, mas também originam algumas ideias e explicações incorretas. A realização de atividades práticas/experimentais, ao envolver ativamente os alunos no processo de aprendizagem, considerando as suas ideias prévias, torna a aprendizagem mais significativa e contribui decisivamente para a evolução conceptual desejável.

Quando se trata de microrganismos, os joveñs, e a esmagadora maioria da população, associa-os à doença atribuindo-lhes uma conotação negativa. Ainda que isso se verifique para muitos microrganismos, há uma vertente benéfica destes seres vivos que os alunos devem conhecer desde cedo. Entre vários exemplos, o papel dos microrganismos na produção de alimentos como o pão ou o iogurte, passa muitas vezes despercebido aos jovens do ensino básico. No entanto, este tema pode ser explorado pela via experimental, nestes anos de escolaridade, contribuindo para uma melhor compreensão do papel destes seres vivos no quotidiano, bem como para os jovens melhorarem o conhecimento do mundo físico-natural envolvente, combatendo uma visão incompleta da biodiversidade e promovendo competências científicas complexas que aumentam a literacia científica.

As atividades que se propõem mostram que, de uma forma descomplicada e com materiais simples, se podem realizar ações de microbiologia na sala de aula, dando aos microrganismos um lugar de destaque e de importância para o Homem. Através das enzimas que produzem, os microrganismos promovem um conjunto de reações químicas (fermentação) em que moléculas orgânicas, geralmente açúcares como a glicose, são desdobrados em produtos mais simples (dióxido de carbono, álcool, etc.) para obter energia. Na fermentação alcoólica, que acontece, por exemplo, para obter pão, as leveduras Saccharomyces cerevisiae (fungos unicelulares) fermentam a glicose formando dióxido de carbono e álcool etílico (etanol). No 
pão é o dióxido de carbono que faz crescer a massa (gera milhares de bolhas que ficam no seu interior). Quando assamos o pão, o dióxido de carbono e as leveduras são destruídos pelo calor e o etanol evapora-se, mas contribui para o aroma e para o paladar do pão.

Para além de outros, a realização destas atividades contempla três grandes objetivos: 1 . Envolver ativamente os alunos no processo de aprendizagem; 2. Demonstrar, pela via experimental, que existem microrganismos benéficos para o Homem, desmitificando a imagem predominantemente negativa que lhes é atribuída; 3. Utilizar o microscópio. As atividades são orientadas por um guião que segue a tipologia POCEA (Prevê - Observa - Compara Explica - Aplica) (Pires, 2014). Os alunos são convidados a fazer previsões (considerando as suas ideias prévias) e observações, bem como a compará-las (que se torna fundamental quando a ideia prévia é diferente da observação, pois, para além de lhes mostrar uma nova ideia, cria motivação e desejo de "encontrar" o porquê da diferença, de explicar o que aconteceu, o que levará à mudança conceptual). Ao criar a oportunidade para os alunos refletirem sobre o que foi observado/evidenciado, promove-se a possibilidade de estabelecerem relações, de fazerem sínteses, de tirarem conclusões, ... A aplicação do conhecimento adquirido em novas situações permitirá que este se consolide e, ao generalizar, que se torne mais útil, atrativo e significativo. Veja as questões problema em aqui.

\section{REFERÊNCIAS}

${ }^{1}$ MAFRA, P., Os microrganismos no 1. ${ }^{\circ}$ e $2 .{ }^{\circ}$ CEB: Abordagem curricular, conceções alternativas e propostas de atividades experimentais. Tese de Doutoramento. U. Minho, 2012.

${ }^{2}$ PIRES, D., Didática das Ciências [Coletânea de textos]. Escola Superior de Educação de Bragança, 2014.

${ }^{3}$ PIRES, D., MAFRA, P., FERNANDES I., O ensino experimental como estratégia de abordagem das ciências: Desenvolvimento de disposições socio-afetivas favoráveis por futuros professores. In: Membiela, P., Casado, N., Cebreiros, M. I. (Eds). Nuevos Escenarios en La Docencia Universitaria, 2016. Ourende: Educación Editora (ISBN: 978-84-15524-32-8). 